\title{
Quantitative Assessment of the Newly MRT System from the Rider's Perspectives
}

\author{
Syahriah Bachok', Muhammad Rijal Mohamad², \\ Oladejo Aliu Olabayonle ${ }^{1}$, Mohammad Zarif Mohd Zahari ${ }^{1}$ \\ 1 Kuliyyah of Architecture and Environmental Design, \\ International Islamic University Malaysia, Kuala Lumpur, Malaysia \\ ${ }^{2}$ Centre of Studies for Town and Regional Planning, \\ Universiti Teknologi MARA, Perak, Malaysia
}

syahriah@iium.edu.my, rijalmohamad@uitm.edu.my, haliyy_4luv@yahoo.com, zarifkoo@gmail.com. Tel: +60 133738995

\begin{abstract}
New rail systems developed in many cities have received significant attention from public transportation researchers globally and regionally. One such system is the Mass Rapid Transit system in Klang Valley, Malaysia. The quality of services' perception has been captured through the questionnaire survey. Preliminary analysis showed that passengers were satisfied and indicated a great willingness to repeat usage. Likewise, dissatisfaction was only expressed on the feeder bus system services to and from the rail stations. This research explains the rationales for the disproportionately high satisfaction levels and betterment of the support infrastructure, including the feeder services.
\end{abstract}

Keywords: high satisfaction, passengers, public transport, rail system

eISSN: 2398-4287@ 2021. The Authors. Published for AMER ABRA cE-Bs by e-International Publishing House, Ltd., UK. This is an open access article under the CC BYNC-ND license (http://creativecommons.org/licenses/by-nc-nd/4.0/). Peer-review under responsibility of AMER (Association of Malaysian Environment-Behaviour Researchers), ABRA (Association of Behavioural Researchers on Asians/Africans/Arabians) and cE-Bs (Centre for Environment-Behaviour Studies), Faculty of Architecture, Planning \& Surveying, Universiti Teknologi MARA, Malaysia.

DOI: https://doi.org/10.21834/ebpj.v6i16.2602

\subsection{Introduction}

Public transportation is an essential support system in the city. An efficient public transportation system contributes to reducing the dependency on a private vehicle. The current agenda in public transportation development is how to achieve sustainability in environmental, social, and economic aspects. The public should equally access the benefit of an efficient public transportation system (Kuo \& Tang, 2013). However, in the current situation, public transportation is still an unfavourable option by the public. This lead to a high dependency on private vehicle in getting access to transportation from $6 \%$ to $23 \%$ in the past decade (Shen et al., 2016). This increase causes severe conflict between motorised and non-motorised, transportation social equal access issues and environmental sustainability (Shen et al., 2016). Therefore, implementable and comprehensive strategies are needed to promote public transportation and offer reliable, efficient, spatial-economic, and environmentally friendly service to urban passengers (Aydin et al., 2015; Baum-Snow et al., 2005; Shen et al., 2016).

The essential criteria for accessing the system's efficiency is the passenger satisfaction and perception of the system. The passenger's perception may be influenced by comfort and convenience during the trips made (Kadir et al., 2020). Typically, the new

eISSN: 2398-4287C 2021. The Authors. Published for AMER ABRA cE-Bs by e-International Publishing House, Ltd., UK. This is an open access article under the CC BYNC-ND license (http://creativecommons.org/licenses/by-nc-nd/4.0/). Peer-review under responsibility of AMER (Association of Malaysian Environment-Behaviour Researchers), ABRA (Association of Behavioural Researchers on Asians/Africans/Arabians) and cE-Bs (Centre for Environment-Behaviour Studies), Faculty of Architecture, Planning \& Surveying, Universiti Teknologi MARA, Malaysia.

DOI: https://doi.org/10.21834/ebpj.v6i16.2602 
public transport system would be perceived as highly satisfactory by the users. This trust among users happened is because the users tend to compare the new system to the older rail system experienced by them and proven through a specific model (Mattsson, 1992). When the new rail system opened the improvement of the system is always taken into consideration to offer ideal quality. There is no clear in defining service quality and satisfaction variable. Both derived from the disconfirmation theory (Parasuraman et al., 1988). Some school of thought believe customer satisfaction causes perceived quality and other service quality as a vehicle for satisfaction (Chen, 2008; Chou \& Kim, 2009).

Accessing passengers' level of passenger satisfaction and perception is essential to encourage ridership and promote the system (Too \& Earl, 2010). Three common reasons are listed for not using the system:1) dissatisfaction with the system, 2) change in job or home location, 3) access to other transportation modes (car ownership and et cetera) or change in family size changes (Van Lierop et al., 2018). For the new system, the efficient system with a better and efficient system to integrate new technology, better facilities, better and efficient services, and strategic station location influencing the passenger's satisfactory level proposed by the authority and government (dell'Olio et al., 2011).

In the Asian context, the respondent is inclined to provide a modest and safe answer (Harzing, 2006; Johnson et al., 2005). This situation happened is because of cultural and intelligence factors (Johnson et al., 2005; Meisenberg \& Williams, 2008). It differs from the western countries and middle eastern where have a higher level of acquaintances (Harzing, 2006). (Meisenberg \& Williams, 2008) Some of the other Asian countries, such as the Philippines, Bangladesh and Pakistan, tend to respond to bias compared to the other Asian countries due to cultural, intellectual, and economic factors. Individual intelligence influences their self-confidence, self-esteem and assertiveness in responding (Meisenberg \& Williams, 2008).

Therefore, a new rail system needs to retain as many regular rail riders as possible and attract new ones (Shen et al., 2016). In this context, this paper intends to explain why the new rail system perceived as highly satisfactory by the passengers expressed by the combination of quality of services, facilities, and convenience. It also explains how the Malaysian provides the response and how it influences the research's satisfaction.

\subsection{Conceptual Framework}

This paper included a few concepts pertinent to accessing the user's level of satisfaction and perception about the rail system, especially on the new rail system. It assesses how the users' satisfaction can be described and tested in terms of quality of services, facilities, and convenience. The rail system should be integrated with all the modern and new system in encouraging ridership. The system should be attractive, comfortable, convenient, proportional and efficient (De Oña \& de Oña, 2014). Therefore, when a new system opened, the passengers' satisfaction is influenced by the efficient system's overall system, facilities, services, and convenience level (He et al., 2016). In this situation, the passenger may shift to the better option and services offered to them with the exact cost. It must equip with efficient support facilities and amenities in terms of facilities, allowing the user to have seamless and hassle-free trips (Marcucci \& Gatta, 2007).

The waiting time is also the criteria look after by the passenger related to the ability to reach the destination as fast as possible. The user needs to rush to their destination. This situation would contribute to healthy competition among the rail transport operator in providing a better service and attract the passenger to continue to use their system instead of the shift to another system. On the other hand, this paper proves that previous research on Asian tends to be modest in responding (Harzing, 2006). The Asian is inclined to give a safe answer due to cultural and other factors (Johnson et al., 2005).

In South-East Asia, the public transportation system is developed and promoted actively. One example is in Klang Valley, Malaysia, as a centre for business and economic activity. The need for transportation is increasing as people are preferred to stay in the outskirt area. There is few urban rail operator and owner in Klang Valley. Mass Rapid Transit system is the new urban rail transportation that previously opened in 2017. The first line is known as Mass Rapid Transit System Sungai Buloh-Kajang Line (SBK Line). MRT owned by MRT Corporation and operated by Prasarana Malaysia Berhad to provide access in the urban area that is not covered by another urban rail in Klang Valley. Therefore, MRT plays a vital role as urban rail in reducing private vehicles' dependency in accessing the urban area. MRT SBK Line's overall service quality needs to be accessed through the user context satisfaction and perception to ensure the mission to get higher ridership can be achieved by the system offered.

\section{i. Defining satisfaction.}

The definition of satisfaction in public transport is defined as the passenger's overall experiences with its services. Therefore, the passenger's perception and opinion about the rail system are essential in determining the next option and alternative for improvement (Eboli \& Mazzulla, 2011).

\section{ii. Quality of Services}

In the context of service quality, it is also determined by the users' satisfaction. The concern aspects of service quality include the reliability of the services, comfort, information, and personnel. The facilities provided at the station also influence the quality of services in the rail transit system (Irfan et al., 2012). On the other hand, all these components have previously tested in other Asian cities in accessing the level of satisfaction. According to (dell'Olio et al., 2011), the variables influencing the service quality of public transportation include 1) time to walk to the initial bus stop, 2) waiting time, journey time, 3) safety features in the vehicle, 4) deviation from optimal route, 5) level of comfort when stopping and restarting the vehicle, 6) comfort experienced during the journey, 7) cleanliness of the vehicle, 8) bus fare, vehicle quality, 9) courtesy showed by the bus driver, and 10) reliability of the vehicle. 


\section{iii. Asian in Providing Response}

In the Asian country context, the respondent tends to respond to modestly (Harzing, 2006). This finding is based on the early studies on differences in responding between countries that typically offered post hoc and limited rationales (Harzing, 2006). The research has been conducted in Malaysia based on three factors such as 1) Power distance, 2) Uncertainty Avoidance, 3) Individualism, 4) Masculinity and 5) GNP Per Capita (Johnson et al., 2005) also personal traits and identity (Meisenberg \& Williams, 2008). The result portrayed that Malaysians tend to give a modest response (Johnson et al., 2005). Most of the respondents providing the predominant response format were disagree, inclined to disagree, unsure, agree, agree. Also, the Japanese and most of the Asian countries often give indirect communication in providing the response through understatement, succinctness and extensively being silent (Harzing, 2006). In the research by (Bennett, 1977), the Chinese tend to be safe in giving a response to selecting the medium scale. Unlike the Philippines' finding, the respondent had a higher tendency to be extremely biased (Bennett, 1977).

\subsection{Methodology}

The off-board questionnaire survey method has been employed in this study between October 2019 and the middle of March 2020. The convenient sampling method has been adopted in this study to get a response from the respondents. The convenient sampling used to make sure the respondent does not feel disturbed and offended during the survey. Another reason is the operator and management's condition to minimise the system's distraction. Most of the respondents were approached nicely at the bus station at the MRT SBK Line station while waiting for the bus or continuing with their road trip. Some 800 MRT riders were asked, but only 511 samples are meant for this study. The survey takes 5 to 7 minutes for each respondent, depending on how fast the response is provided. 5 to 7 minutes allocated to avoid the distraction in the respondent's travel time. The sample focuses on the service user as the frequent user have a strong opinion about the system (Van Lierop et al., 2018).

The targeted group of respondent same as the study done by (Aydin et al., 2015), which focuses on the rail user. The survey started back in October 2019 where the pandemic is still not detected in China and finish in the middle of March, right before the Covid 19 pandemic severely attacked in Malaysia. There are only 553 Covid 19 cases reported in Malaysia between January to $16^{\text {th }}$ March 2020. There is no difference in satisfaction level identified before and during the Covid 19 Pandemic because the Malaysian government is imposed the Movement Control Order on 16th March 2020, where the survey was already done. The difference is expected if the survey takes place during the Movement Control Order and later. In between January to March 2020, where the early infection in Malaysia, there is no difference in collecting the sample as people still work as usual and not so worry about the situation.

The questionnaire consists of three main sections. The questionnaire is formed according to the previous studies' variables on the accessibility and after the pilot survey. The first section was used to get collect the trip information and characteristic. The second section was about the user opinion on the system service quality, facilities and convenience, and the last section is where the user information was captured. The user information becomes the last section to ensure the respondents are not feeling offended by the questions. It is also to show respect towards the user's confidentiality of their private information. There were four scales of assessment for the user to classify the level-of-service quality, facilities, and conveniently named unsatisfied, unsatisfied, satisfied, and satisfied.

The evaluation was including the facilities design and comfort, signage, facilities and service convenience, pedestrian facilities, waiting time, transport mode changing time, parking, and overall satisfaction to get collect the responses. All these variables tested based on the facilities and services offered by the MRT SBK Line system.

MRT SBK Line is the newest urban rail system in Klang Valley, where previously the roles are solely played by KTM Commuter with the limit boundaries area. MRT SBK Line's has covered a new range area to serve the need for transportation. MRT SBK Line has covered the area which not accessible by the rail transportation previously such as Damansara, Sungai Buloh area. This area shows high demand for transportation as the city expansion has reached all these areas. The MRT SBK Line opening allows and promotes high connectivity between these areas to Kuala Lumpur City Centre. It also helps in reducing the traffic pressure on the road. The user has a new option to make a trip to these areas. Previously, these areas are only accessible by bus and taxis. The MRT SBK Line development allows the user to get convenient access to these areas. Most of them are the bus user previously. The change the mode because the bus services always delay as these areas are congested, especially during peak hours. MRT SBK Line provides seamless and congestion-free services that allow the user to save their time effectively. Therefore, this research focuses only on MRT SBK Line as there are no other rail services in these areas. The MRT SBK Line is also connected to the interchange station, such as Muzium Negara and Pasar Seni. These stations allow the passenger to change to the other rail and mode transportation such as Rapid KI Bus, Go KL City Bus, taxis and Grab. In Kuala Lumpur, there are few other rail systems such as Light Rail Line (LRT), Monorail, KLIA Express, KTM Komuter. All these rail systems are available and connected with MRT SBK Line. This variety option of rail system allows the passenger to make multiple trips. Therefore, passengers' selection as samples at the MRT SBK Line's selected station represents the level of satisfaction and perception study for the new urban rail study.

\subsection{Findings and Discussion}

\section{i. Socio-Demographic}


$57 \%$ of the respondents intercepted were female, while another $43 \%$ were male. The majority of the respondents had college or university level qualifications (54\%), while another (46\%) is a school leaver. A significant portion of school or higher education students. The passengers were privately employed (46.3\%), and only a tiny number worked in the government sector (3.8\%). This result portrayed that most of the respondents tend to be educated, demanded, sophisticated, or specialised services and were highly mobile with a variety of transportation mode choice. Another one per cents were withered retirees or homemakers, or the unemployed.

In term of household income level, most of the respondent earned between RM 2000-RM 5000 monthly (38.9\%), where another (32.6\%) of them brought between Rm 5001- RM10,000 monthly. Only a minority (8.5\%) reported a household RM 10,000 and above, and (9\%) earned RM 1000 and below.

\section{ii. Trip Information and User opinion}

The passengers were intercepted in ten MRT SBK Line stations which have been identified. The ten stations are including Bandar Utama, Phileo Damansara, Pusat Bandar Damansara, Muzium Negara, Maluri, Taman Midah, Taman Suntex, Bandar Tun Hussien Onn, Sri Raya, and Bukit Dukung. Majority of the respondent was intercepted at the SBK Maluri Station (17.6\%) followed by Muzium Negara $(15.9 \%)$ and followed by the other nine stations with a lower ridership percentage. A high percentage of passengers make a trip purposely for school/work or return home (66.4\%) and shop and leisure (19.6\%), respectively. It is in line with the result portrayed in the socio-demographic, which showed that most of the respondents intercepted are college and university students.

\subsection{Descriptive analysis}

Based on the previous study was done in the other countries, various analysis method has been employed, including the structural equation model (Kuo \& Tang, 2013; Shen et al., 2016; Wang et al., 2020; Yilmaz \& Ari, 2017), fuzzy-Choquet integral (Aydin et al., 2015). Most of the study is using the structural equation model as a method of analysis. In this research, the descriptive analysis is employed to prove why the respondents express their satisfaction (Tripodi \& Bender, 2010; Zapko et al., 2018). Further analysis to be conducted to prove the level of accessibility and level of service quality of the system as done by the previous researcher (Kuo \& Tang, 2013; Shen et al., 2016; Wang et al., 2020; Yilmaz \& Ari, 2017). According to the survey, the passengers' satisfaction and perception towards the MRT SBK Line stations' facilities and services were high. The data was tabulated as below:

Table1: Passenger satisfaction and perception of facilities and services provided in the MRT SBK Line stations.

\begin{tabular}{|c|c|c|c|c|}
\hline \multirow[t]{2}{*}{ ELEMENT } & \multicolumn{4}{|c|}{ ASSESSMENT LEVEL } \\
\hline & $\begin{array}{c}\text { Very } \\
\text { Dissatisfied } \\
\%\end{array}$ & $\begin{array}{l}\text { Dissatisfied } \\
\%\end{array}$ & $\begin{array}{l}\text { Satisfied } \\
\%\end{array}$ & $\begin{array}{c}\text { Very } \\
\text { Satisfied } \\
\%\end{array}$ \\
\hline \multicolumn{5}{|c|}{ Facilities } \\
\hline Trip Information & 1.2 & 1.5 & 54.4 & 42.9 \\
\hline Waiting Facilities & 1.0 & 4.8 & 51.7 & 42.5 \\
\hline Lift & 1.2 & 2.2 & 52.4 & 44.2 \\
\hline Stairs/ Escalator & 1.0 & 2.5 & 47.6 & 48.9 \\
\hline Disable Friendly Facilities & 1.0 & 4.5 & 56.9 & 37.6 \\
\hline Number of coaches & 0.8 & 3.9 & 50.7 & 44.6 \\
\hline Coach Seat & 1.2 & 5.4 & 51.5 & 41.9 \\
\hline Trip Frequency & 1.2 & 5.1 & 50.1 & 43.6 \\
\hline Benches & 1.2 & 4.8 & 52.3 & 41.7 \\
\hline Ticketing Machine & 0.8 & 5.4 & 55.8 & 38.0 \\
\hline Safety Facilities & 1.0 & 2.4 & 52.8 & 43.8 \\
\hline Emergency Facilities & 0.6 & 2.2 & 53.0 & 44.2 \\
\hline \multicolumn{5}{|c|}{ Signage } \\
\hline Signage Visibility & 0.8 & 4.1 & 55.2 & 39.9 \\
\hline Signage Effectiveness & 1.0 & 3.5 & 56.0 & 39.5 \\
\hline Signage Location & 0.6 & 3.7 & 54.2 & 41.5 \\
\hline \multicolumn{5}{|c|}{ Convenient } \\
\hline Station location & 0.8 & 4.1 & 50.7 & 44.4 \\
\hline Staff & 1.0 & 2.1 & 56.6 & 40.3 \\
\hline Comfort & 0.9 & 2.9 & 48.3 & 47.9 \\
\hline Sense of Safety & 0.8 & 2.7 & 53.4 & 43.1 \\
\hline Varieties of Shop & 1.2 & 12.1 & 55.4 & 31.3 \\
\hline Assembly area & 1.2 & 2.5 & 52.3 & 44.0 \\
\hline Surau/Musolla & 0.6 & 2.3 & 49.5 & 47.6 \\
\hline Toilet & 0.8 & 3.5 & 44.8 & 50.9 \\
\hline \multicolumn{5}{|c|}{ Pedestrian Facilities } \\
\hline Pedestrian Walkway & 0.8 & 6.4 & 54.4 & 38.4 \\
\hline Roofed Walkway & 0.8 & 4.9 & 53.0 & 41.3 \\
\hline Walkway Pavement & 0.6 & 3.3 & 49.7 & 46.4 \\
\hline Crosswalk & 1.5 & 4.1 & 51.5 & 42.9 \\
\hline \multicolumn{5}{|c|}{ Time } \\
\hline $\begin{array}{l}\text { Distance from another mode of transport } \\
\text { to MRT Waiting Space }\end{array}$ & 0.8 & 7.8 & 50.5 & 40.9 \\
\hline MRT Waiting Time & 1.4 & 5.9 & 48.9 & 43.8 \\
\hline
\end{tabular}




\begin{tabular}{|c|c|c|c|c|}
\hline Other mode waiting time & 3.5 & 13.6 & 53.2 & 29.7 \\
\hline \multicolumn{3}{|c|}{ Parking } \\
\hline Parking Space & 1.4 & 3.9 & 70.1 & 21.3 \\
\hline Parking Fees & 1.0 & 2.7 & 70.6 & 22.3 \\
\hline Parking Safety & 0.4 & 4.1 & 71.0 & 21.1 \\
\hline \multicolumn{3}{|c|}{ Overall Satisfaction } \\
\hline Origin to Station & 0.6 & 2.3 & 57.1 & 39.9 \\
\hline Station to Destination & 0.4 & 2.2 & 54.8 & 42.7 \\
\hline Station to house & 0.6 & 2.0 & 56.4 & 41.1 \\
\hline Station to workplace/school/college & 0.6 & 2.3 & 51.9 & 45.2 \\
\hline
\end{tabular}

Table 1 above shows every item's results under seven components of facilities and services provided at the MRT SBK Line stations. The assessment was formed based on that component and item above.

Table 1 above portrayed that all the item has a high satisfaction level for almost all the item and component. Under the facilities component, most passengers show high satisfaction with trip information (97.3\%). Same as for the signage component, the effectiveness scores high satisfaction (95.5\%). For the convenient component, it shows that high satisfaction for the toilet with (95.7\%). In pedestrian facilities, most of the respondents were happy with pavements (96.1\%). Waiting and transfer time component, high satisfaction among the respondents for MRT Waiting time (92.7\%). Under the parking and overall satisfaction component, parking fees and the house's station get very high satisfaction (92.9\%) and (97.5\%). In line with the study done by (Kuo \& Tang, 2013), this finding found that service quality directly influences behavioural intention, safety, and security (Shen et al., 2016), which fall under the rail user's convenience. Figure 1 below shows the MRT SBK Line station facilities, which are convenient and newly developed and equipped with modern design and technology.
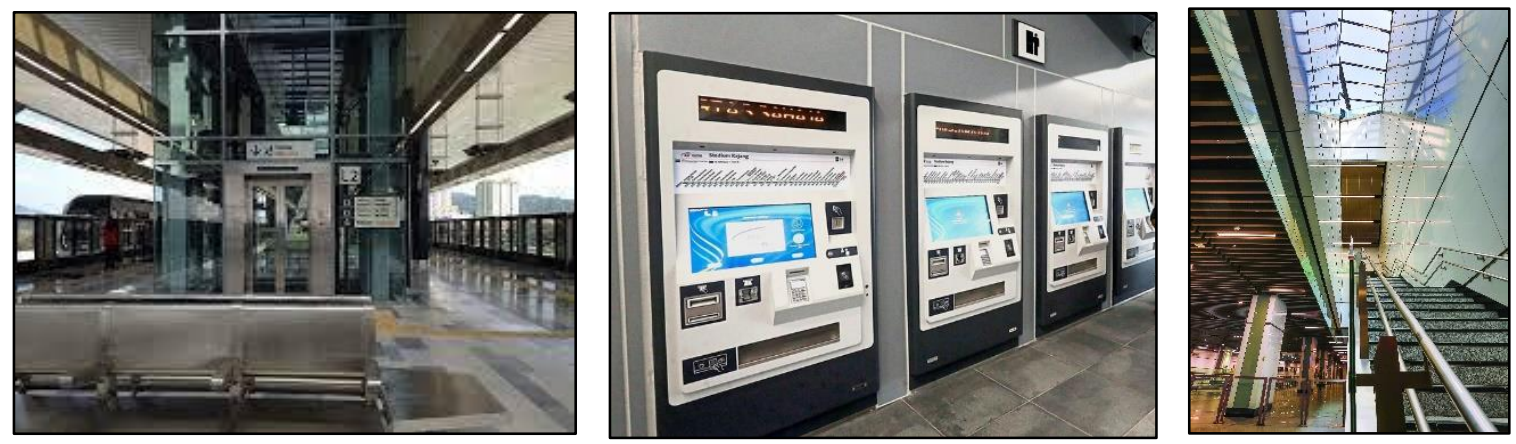

Figure 1: Facilities at the MRT Station (1. Benches and Lift, 2. Modern Ticketing System, 3. Proper Stair).

Compared with the study on the perception of KTM Komuter services in Klang Valley, $78 \%$ feel dissatisfied with the services provided when the riders faced the delayed experience (Khalid et al., 2014). The majority of the respondents (26\% to $30 \%$ ) also perceived that the KTM Komuter train's waiting time is in the frequency of 15 minutes, and about (16\% to $21 \%$ ) believed that the KTM Komuter frequency on 30 minutes. Therefore, between these two suburban rail system in Klang Valley, it portrayed that the latest MRT SBK Line is much improved, and the system trusted among the riders (92.7\%) respondents satisfied with the waiting time, which in between 5 to 7 minutes intervals (Khalid et al., 2014). The waiting time is one of the main issues highlighted by the KTM Komuter users, affecting the KTM Komuter system. On the other hand, KTM station facilities issues also highlighted, especially on the walking transfer facilities to accommodate the needs of rider for other bus and rail system (Bachok et al., 2013), and the walking facilities found as not weatherproofed and less disabled friendly and can also be unsafe for women users travelling during the late evening hour (Bachok et al., 2013).

According to the MRT SBK Line survey result above, most of the component gets a very high satisfaction level with more than $90 \%$.

Table 2: Passenger satisfaction and perception feeder bus facilities and services provided at the MRT SBK Line stations.

\begin{tabular}{|c|c|c|c|c|}
\hline \multirow[t]{2}{*}{ ELEMENT } & \multicolumn{4}{|c|}{ ASSESSMENT LEVEL } \\
\hline & $\begin{array}{c}\text { Very } \\
\text { Dissatisfied } \\
\%\end{array}$ & $\begin{array}{c}\text { Dissatisfied } \\
\%\end{array}$ & $\begin{array}{c}\text { Satisfied } \\
\%\end{array}$ & $\begin{array}{c}\text { Very Satisfied } \\
\%\end{array}$ \\
\hline \multicolumn{5}{|c|}{ Convenient } \\
\hline Information and Guidance & 1.4 & 8.9 & 60.3 & 29.4 \\
\hline Ease of boarding-Alighting Bus & 1.4 & 3.7 & 59.3 & 35.5 \\
\hline Seat Availability & 4.2 & 6.1 & 60.7 & 29.0 \\
\hline Seat Comfort & 2.8 & 7.5 & 63.6 & 26.2 \\
\hline Crowdedness in-vehicle & 3.7 & 6.5 & 63.6 & 26.2 \\
\hline Air-conditioning in-vehicle & 2.3 & 2.8 & 61.2 & 33.6 \\
\hline Cleaning in-vehicle & 3.7 & 4.7 & 60.7 & 30.8 \\
\hline Physical condition & 1.9 & 2.8 & 65.0 & 30.4 \\
\hline Other bus user behavior & 1.4 & 6.1 & 63.6 & 29.0 \\
\hline Vehicle Breakdown & 1.9 & 3.3 & 61.2 & 33.6 \\
\hline
\end{tabular}




\begin{tabular}{|c|c|c|c|c|}
\hline The passage between rows of seats & 1.9 & 3.3 & 65.4 & 29.4 \\
\hline \multicolumn{4}{|c|}{ Reliability of Bus Service } \\
\hline Bus arrives on time & 12.1 & 29.9 & 43.9 & 14.0 \\
\hline Bus departs on time & 15.4 & 24.8 & 46.7 & 13.1 \\
\hline Travel time & 11.7 & 27.6 & 50.9 & 9.8 \\
\hline Service Frequency & 7.9 & 30.4 & 45.3 & 16.4 \\
\hline Safety on bus & 0.9 & 7.9 & 64.5 & 26.6 \\
\hline Other bus user behaviour & 1.4 & 4.7 & 65.0 & 29.0 \\
\hline \multicolumn{5}{|c|}{ Bus condition } \\
\hline The appearance of the bus & 1.4 & 5.1 & 53.7 & 39.7 \\
\hline Bus cleanliness & 4.2 & 6.1 & 52.3 & 37.4 \\
\hline Storage availability on the bus & 1.9 & 9.3 & 50.0 & 38.8 \\
\hline Provision and visibility of the handrails & 1.4 & 3.7 & 58.4 & 36.4 \\
\hline Bus spaciousness & 1.4 & 5.1 & 53.7 & 39.7 \\
\hline
\end{tabular}

Table 2 shows every item is finding under three selected components of facilities and services for the MRT SBK Line Stations' feeder bus. The selection of the item and component is based on the availability of the facilities and services provided.
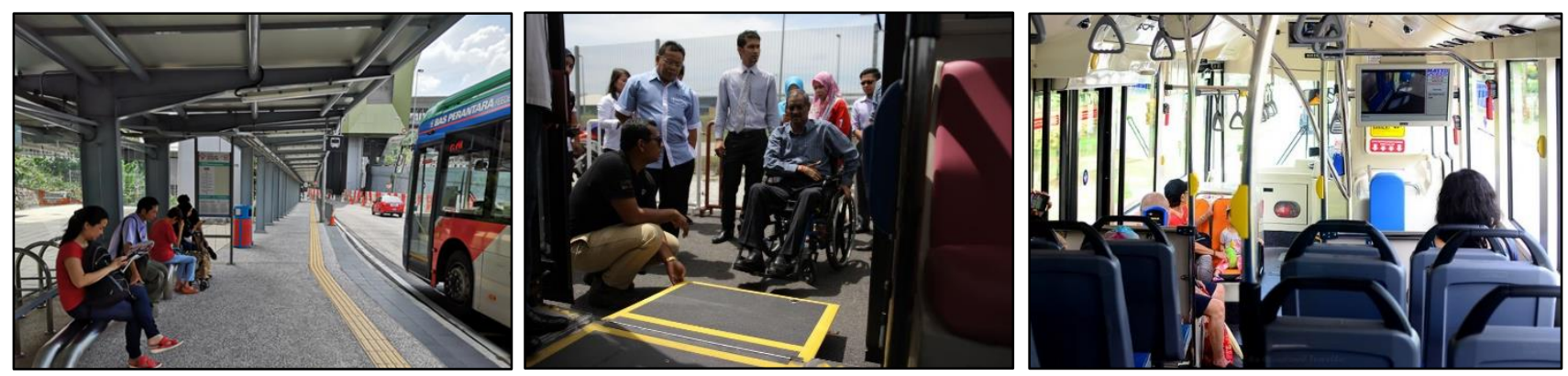

Figure 2: MRT Bus Condition (1. Feeder Bus Waiting Facilities with Tactile Block, 2. Wheelchair Friendly, 3. Bus Interior Design)

Table 2 above shows that almost all the items for convenient component rated as high satisfaction by the user. Figure 2 show the MRT Feeder bus facilities condition and design. The highest satisfaction under convenient component is a physical condition (95.4\%), ease of boarding, air-conditioning in-vehicle and passage between rows of seats (94.8\%). There are some differences portrayed under the reliability of the bus service component. The satisfaction and dissatisfaction on the service reliability are almost balance except for safety on the bus where the operator never tolerate any behavioural issues that affect their operation and service quality (94\%) and jeopardise passenger safety (91.1\%). According to the finding, it is proven that even the feeder bus is the new system provided as a service package with the MRT, it might not guarantee the same satisfaction between these two services even owned and operated by the same organisation. There are no issues in the bus condition, and the respondents' high satisfaction as the bus is well maintained and environmentally friendly. The provision and visibility of the handrails (94.8\%) and appearance of the bus and bus spaciousness $(93.4 \%)$ get a very high satisfaction, respectively.

\subsection{Recommendation and Conclusions}

This paper is proved that the new rail system portrays very high satisfaction among the users. The investment is made to equip the new rail system and employ advanced and modern technology to cater to its needs (Edwards, 2013). The station facilities are still new and well maintained by the management (Edwards, 2013). Both elements are essential in measuring service quality and proved through the research (Kuo \& Tang, 2013). According to research by (Kuo \& Tang, 2013), service quality satisfaction is influenced by the excellent system services and facilities. This paper also proved that the theory of Asian tends to give a muted response in relevance. Most of the respondents are answering between satisfied and most satisfied in the questionnaire survey. This finding supports the research on how the Asian giving a response by (Harzing, 2006).

The respondents have shown reasonable satisfaction with the service provided in terms of feeder services, especially on the bus services' reliability, particularly on the bus arrival (57.9\%) and departure (59.8\%). It is proved that; the respondent needs to wait for long for the feeder to and from the stations. The extra cost has to bear by the users to wait for the feeder. As an alternative, the respondents need to find another option through grab or taxis to save time (Armstrong-Wright \& Thiriez, 1987). The respondent's low satisfaction is happened due to different personality traits and identity (Meisenberg \& Williams, 2008).

According to research finding, the feeder bus trip frequency needs to be added to reduce the waiting time for departure and arrival. The more frequency offered helps reduce the waiting time for the departure and arrival because the heavy and crucial traffic in the area might be the reason for the feeder's lateness (Suwardo et al., 2009). the traffic causes the bus caught in congestion in their trips from the stations (Suwardo et al., 2009). Therefore, when the trip frequency increases, more trips can be made to and from the station. It can allow the feeder to access more significant coverage area and collect more passenger to and from the stations in a future context 
(Rohani et al., 2013; Suwardo et al., 2009). Therefore, the better system offered by the feeder bus, the higher the ridership number of MRT can be expected in the future time. The operation cost can be reduced and optimised (Tirachini et al., 2010). This finding and recommendation are proved and supported by (Dandapat et al., 2014; Rohani et al., 2013; Suwardo et al., 2009), which stated that the bus's ridership rate could be addressed with good scheduling and increase the number of trips. Simultaneously, the increment in ridership number is expected as the system's reliability has improved (Dandapat et al., 2014).

In conclusion, this paper has explored and described the satisfaction and perception of the MRT SBK Line, and it is the feeder bus user in Klang Valley. The rail operator and owner should focus on the feeder bus services that are more user-friendly, punctual, and well-assessable to get higher user satisfaction and directly increase the MRT SBK Line ridership in future. The feeder bus is supposed to be a support system for the MRT because it is an intermediate system to bring people from their origin point to the stations and from the station to their destination. Besides that, based on the finding majority of the respondent exhibit the high satisfaction for most of the MRT SBK Line services proved the theory that the Asian countries respondent is modest in giving their opinion due to the cultural, intellectual and economic factors (Johnson et al., 2005; Meisenberg \& Williams, 2008).

The studies had several limitations to this study. Only ten stations were selected. The limited number of users in the other and less cooperative of the respondent has limited the potential to collect more sample varieties. It can be overcome by hiring a massive number of enumerators. Second, the research relies only on the primary data, and the secondary data cannot be verified as the MRT owner and operator refused to share all the information. In the future, the research on the satisfaction among the disabled group on MRT SBK Line or newly developed MRT SSP Line in Klang Valley.

\section{Acknowledgements}

This paper is prepared to support the MRT SBK Line's research, and it is the feeder bus in Klang Valley, Malaysia. Thank you to Prasarana Malaysia as MRT SBK Line operator who provided the research team's permission and work permit in doing the survey. All the enumerators and research teams have worked hard to ensure the data collection process is well-planned. To the respondents, your time and kind cooperation were highly appreciated.

\section{Paper Contribution to Related Field of Study}

This paper exposes the researchers in the urban rail study that the respondents inclined to give a positive answer during the survey session. Therefore, due to this complexity to get essential data, the study relating to urban rail as a subject matter might require researchers a vast number of samples and extra effort. On the other hand, a different way of conducting the survey is needed to make the respondent more comfortable expressing their opinions.

\section{References}

Armstrong-Wright, A., \& Thiriez, S. (1987). Bus services: reducing costs, raising standards (Issue TP-68).

Aydin, N., Celik, E., \& Gumus, A. T. (2015). A hierarchical customer satisfaction framework for evaluating rail transit systems of Istanbul. Transportation Research Part A: Policy and Practice, $77,61-81$.

Bachok, S., Osman, M. M., Khalid, U. A., \& Ibrahim, M. (2013). COMMUTERS PERCEPTIONS ON RAIL BASED PUBLIC TRANSPORT SERVICES: A CASE STUDY OF KTM KOMUTER IN KUALA LUMPUR CITY, MALAYSIA. PLANNING MALAYSIA, 11(3).

Baum-Snow, N., Kahn, M. E., \& Voith, R. (2005). Effects of urban rail transit expansions: Evidence from sixteen cities, $1970-2000$ [with comment]. Brookings-Wharton Papers on Urban Affairs, 147-206.

Bennett, M. (1977). RESPONSE CHARACTERISTICS OF BILINGUAL MANAGERS TO ORGANISATIONAL QUESTIONNAIRES 1. Personnel Psychology, 30(1), 2936 .

Dandapat, S., Maitra, B., \& Phanikumar, C. V. (2014). Is Bus Fare the Only Concern to Urban Trip Makers'? An Experience in Kolkata. Indian Highways, 65.

dell'Olio, L., Ibeas, A., \& Cecin, P. (2011). The quality of service desired by public transport users. Transport Policy, 18(1), 217-227.

https://doi.org/10.1016/J.TRANPOL.2010.08.005

Edwards, B. (2013). The modern station: new approaches to railway architecture. Taylor \& Francis.

Harzing, A.-W. (2006). Response Styles in Cross-National Survey Research: A 26-Country Study. International Journal of Cross-Cultural Management, 6, 243-266. https://doi.org/10.1177/1470595806066332

He, L., Liang, Q., \& Fang, S. (2016). Challenges and innovative solutions in urban rail transit network operations and management: China's Guangzhou metro experience. Urban Rail Transit, 2(1), 33-45.

Johnson, T., Kulesa, P., Cho, Y. I., \& Shavitt, S. (2005). The relation between culture and response styles: Evidence from 19 countries. Journal of Cross-Cultural Psychology, 36(2), 264-277.

Khalid, U. A., Bachok, S., Osman, M. M., \& Ibrahim, M. (2014). User perceptions of rail public transport services in Kuala Lumpur, Malaysia: KTM Komuter. Procedia- 
Social and Behavioral Sciences, 153, 566-573.

Kuo, C., \& Tang, M. (2013). Relationships among service quality, corporate image, customer satisfaction, and behavioral intention for the elderly in high speed rail services. Journal of Advanced Transportation, 47(5), 512-525.

Meisenberg, G., \& Williams, A. (2008). Are acquiescent and extreme response styles related to low intelligence and education? Personality and Individual Differences, 44(7), 1539-1550.

Rohani, M. M., Wijeyesekera, D. C., \& Karim, A. T. A. (2013). Bus operation, quality service and the role of bus provider and driver. Procedia Engineering, $53,167-178$.

Shen, W., Xiao, W., \& Wang, X. (2016). Passenger satisfaction evaluation model for Urban rail transit: A structural equation modelling based on partial least squares. Transport Policy, 46, 20-31.

Suwardo, W., Napiah, M., \& Kamaruddin, I. (2009). On-time performance and service regularity of stage buses in mixed traffic. International Journal of Business, Economics, Finance and Management Sciences 1: 3 2009, 1(3), 176-183.

Tirachini, A., Hensher, D., \& Jara-Díaz, S. (2010). Comparing operator and users costs of light rail, heavy rail and bus rapid transit over a radial public transport network. Research in Transportation Economics, 29, 231-242. https://doi.org/10.1016/j.retrec.2010.07.029

Tripodi, S., \& Bender, K. (2010). Descriptive studies. The Handbook of Social Work Research Methods, 2, 120-130.

Van Lierop, D., Badami, M. G., \& El-Geneidy, A. M. (2018). What influences satisfaction and loyalty in public transport? A review of the literature. Transport Reviews, $38(1), 52-72$.

Wang, Y., Zhang, Z., Zhu, M., \& Wang, H. (2020). The impact of service quality and customer satisfaction on reuse intention in urban rail transit in Tianjin, China. SAGE Open, 10(1), 2158244019898803.

Yilmaz, V., \& Ari, E. (2017). The effects of service quality, image, and customer satisfaction on customer complaints and loyalty in high-speed rail service in Turkey: a proposal of the structural equation model. Transportmetrica A: Transport Science, 13(1), 67-90.

Zapko, K. A., Ferranto, M. L. G., Blasiman, R., \& Shelestak, D. (2018). Evaluating best educational practices, student satisfaction, and self-confidence in simulation: A descriptive study. Nurse Education Today, 60, 28-34. 